\title{
GLOMERULAR PERMEABILITY STUDIED BY ELECTRON MICROSCOPY
}

\author{
SADAO KAWAMURA \\ Department of Pathology, School of Medicine \\ Keio University, Tokyo
}

(Received for publication July 24, 1961)

\section{INTRODUCTION}

Recently, not only in glomerulonephritis but also in nephrotic syndrome or nephrosis, glomerular changes have been thought to be of primary pathological foci. (1-7) Therefore it is natural that men have attached great importance to glomerular permeability which is the basic function of the glomerulus and studied in many ways. However, without mentioning the significance of the existing cells in the glomerulus, they have tried to discuss it mainly by calculating the diameters of small openings which are supposed to exist or can be actually seen by electron microscopy in the basement membrane and its inside and outside layers, endothelium and epithelium of the glomerular capillary wall.(8-14) Pappenheimer's explanation of glomerular permeability by diffusion or active transport is also a physical explanation presupposing small openings and it is quite doubtful if the explanation may be applied biologically

\section{Possible pathways of substances}

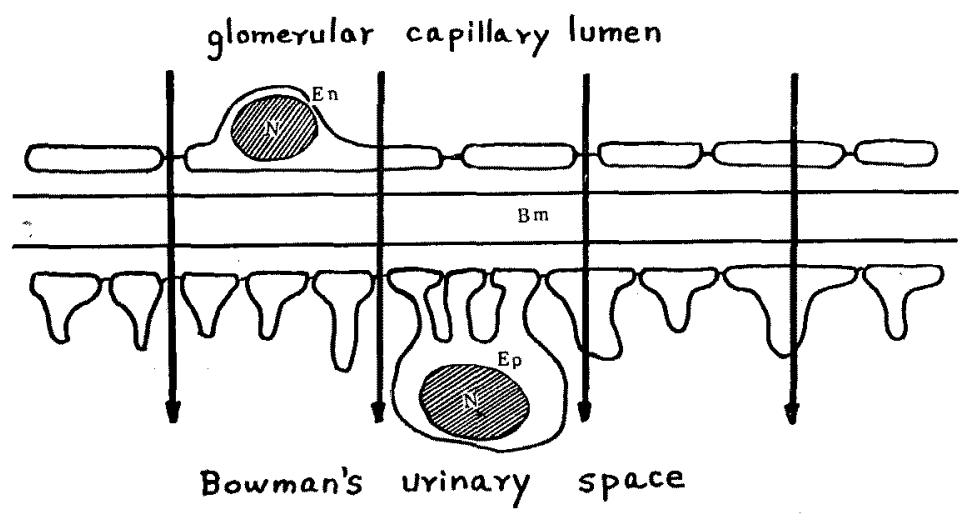

Fig. 1 
as is expected. Namely, do substances permeate through only the small openings? Or do not both endo-, and epithelial cells take part in glomerular permeability? If do participate, through which pathway do they penetrate as indicated in Fig. 1?

In 1960 Farquhar et al. gave us some clues to analyse the pathway of substances in penetrating the glomerular capillary wall in her study of the mechanism by which proteins are segregated into droplets by the epithelium of glomerular capillaries with the aid of ferritin as a tracer. (15) The author has also made attempts to analyse some facts in glomerular permeability using a several tracers which can be seen under an electron microscope, comparing their suitabilities to electron microscopic study at the same time.

\section{MATERIALS AND METHODS}

(1) Four ml of Urographin which is a contrast medium of iodine of the urinary tract was injected into the ear vein of a rabbit weighing $2 \mathrm{~kg}$, which, 5 minutes later, was sacrificed and the kidney was removed, cut into small pieces and fixed in $1 \% \mathrm{OsO}_{4}$ solution buffered at $\mathrm{pH} 7.2$ by veronal acetate buffer solution with $0.25 \mathrm{M}$. sucrose for 2 hours, dehydrated in alcohol and embedded in $1: 4$ mixture of methyl and n-butyl methacrylate.

(2) Three $\mathrm{ml}$ of fatty emulsion (FATGEN: DAINIPPON PHARMACEUTICAL CO., LTD., OSAKA, JAPAN), specially prepared for intravenous injection, was administered into the renal artery of a rabbit which was immediately sacrificed and the kidney was removed, cut, fixed, dehydrated and embedded in the same way as mentioned above.

\section{Table 1}

The fourth method

\begin{tabular}{|c|c|c|c|c|c|}
\hline & $\begin{array}{c}\text { Body } \\
\text { weight } \\
\text { (g) }\end{array}$ & $\begin{array}{c}\text { Dose of one } \\
\text { injection } \\
(\mathrm{mg} \mathrm{Fe} / \mathrm{kg})\end{array}$ & $\begin{array}{l}\text { Frequency } \\
\text { of injection }\end{array}$ & $\begin{array}{l}\text { Total dose } \\
\text { (mg Fe) }\end{array}$ & $\begin{array}{c}\text { hours of } \\
\text { sacrifice } \\
\text { after, the last } \\
\text { injection }\end{array}$ \\
\hline A & 2600 & 100 & 1 & 260 & 6 \\
\hline B & 2500 & 75 & 1 & 188 & 12 \\
\hline $\mathrm{C}$ & 2900 & 75 & 1 & 218 & 24 \\
\hline D. & 3300 & 75 & $3 *$ & 740 & 24 \\
\hline$E$ & 2900 & 75 & 6 奖 & 1305 & 24 \\
\hline
\end{tabular}

* every other day (three times a week) 
(3) Five $\mathrm{ml}$ of Imferon (BENGER LABORATORIES LTD., HOLMES CHAPEL, CHESHIRE, ENGLAND) which is a stable solution of iron dextran complex for the treatment of iron deficiency anemia, containing $50 \mathrm{mg}$ elemental iron per $\mathrm{ml}$, injected intravenously to two rabbits weighing about $2 \mathrm{~kg}$, whose kidneys were removed after 5 and 10 minutes respectively.

(4) Imferon was administered to 5 rabbits weighing from 2.5 to $3.3 \mathrm{~kg}$ according to Golberg, Smith and Martin's method as indicated in Table 1.(17)

In the series of these methods, light microscopical specimens were made as well and iron staining was performed as occasions demanded in the third and fourth methods.

\section{OBSERVATIONS}

(1) Urographin appeared to be unsuitable as a tracer since it was not found electron microscopically in the shape of particles even in the glomerular capillary lumen. No change in any part of the glomerulus was observed.

(2) The fatty particles of Fatgen showed considerable density taking $\mathrm{OsO}_{4}$. They were too large to study the glomerular permeability though presumably suitable for any other purposes.

The methods (1) and (2) were preliminary attempts resulting in unsuccessfulness and no further trials were made in these series.

Findings in the third and fourth methods are explained in the lump as shown in Fig. 2.
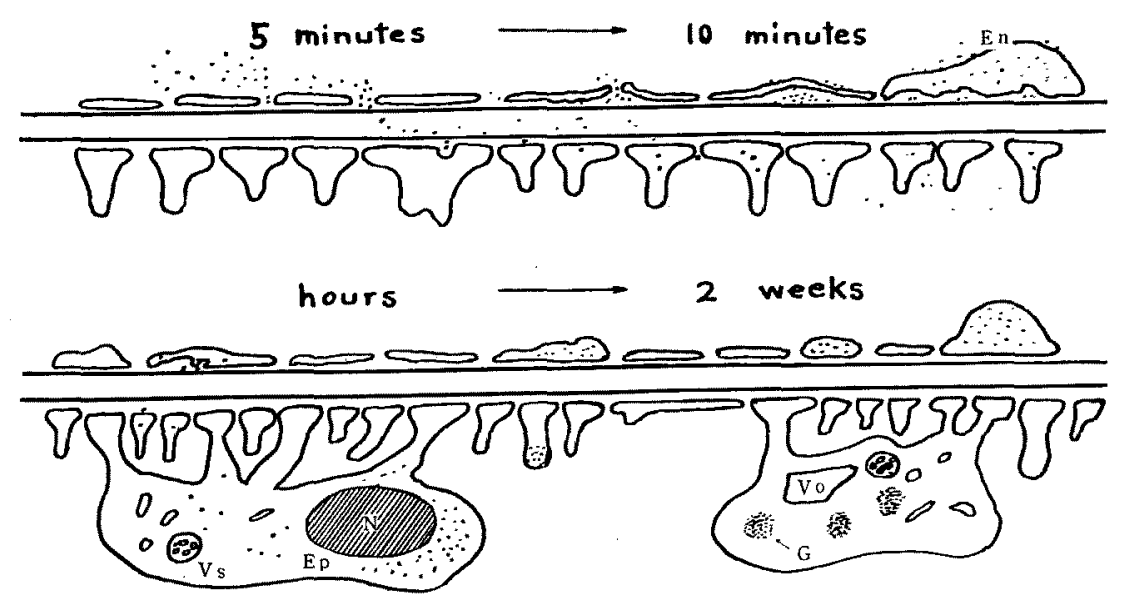

Fig. 2 
In 5 minutes following intravenous injection, iron dextran complex were observed as small particles with round and distinct borders showing high density only in the glomerular capillary lumen where no such particles are normally seen (Fig. 5). The particles measure approximately $70 \dot{A}$ in diameter, nearly resembling to the one measured by electron microscopy at EISAI Co., LTD., TOKYo, JAPAN. (18) Then the particles penetrated through the endothelial openings into the lamina lucida interna and the basement membrane (Fig. 6).

Ten minutes after on, they were seen in every height in the basement membrane, lamina lucida externa and already in the epithelial foot processes with or without invagination of the investment of the epithelial cells (Fig. 7). In the same period the particles were also seen on the surface of the endothelial cells and in their cytoplasm without invagination of the cell membrane or intracellular vesiculation (Fig. 8). There was, at the same time, waved irregularity of the thin endothelial layer beneath which the particles were seen in the edematously enlarged internal lucid layer (50-125 milimicron wide) (Fig. 9). At this time no other particular changes of the structures or Palade's granules in the cytoplasm of the endothelial cells could be observed. These findings suggest us a possibility that the iron particles (ferric hydroxide) would directly penetrate into and out of the endothelial cells. Then the particles were seen in the Bowman's urinary space (Fig. 10) and very rarely seen between the foot processes (Fig. 11).

The findings mentioned above occurred within ten minutes, as well as in six to twelve hours in the method (4) A and B (Fig. 12) that possibly indicates the difference between intravenous and intramuscular injections. However, in twelve hours in the visceral epithelial cells were increased vesicular structures such as rough-surfaced endoplasmic reticulum, vesicles (Fig. 13) and vacuoles (Fig. 14), in which considerable numbers of iron particles with distinct borders and sometimes halo around each of them were encountered.

As time went by, the particles increased in number and scattered throughout the epithelial cells which consequently appeared dark for twenty four hours (Fig. 15). Then the particles formed themselves groups in the cytoplasm which became positive for iron staining (Fig. 16).

Regarding the mesangial cells, iron particles, which penetrated into the subendothelial spaces (mesangial matrix) (Fig. 17) were taken in the mesangial cells within ten minutes (Fig. 18). In a week they grouped togather, becoming positive for iron staining in the same manner as in the epithelial cells (Fig. 19). The behavior of iron particles in the mesangium is shown in Fig. 3.

As to the endo-, and epithelial cells in a week or two, a several findings could 


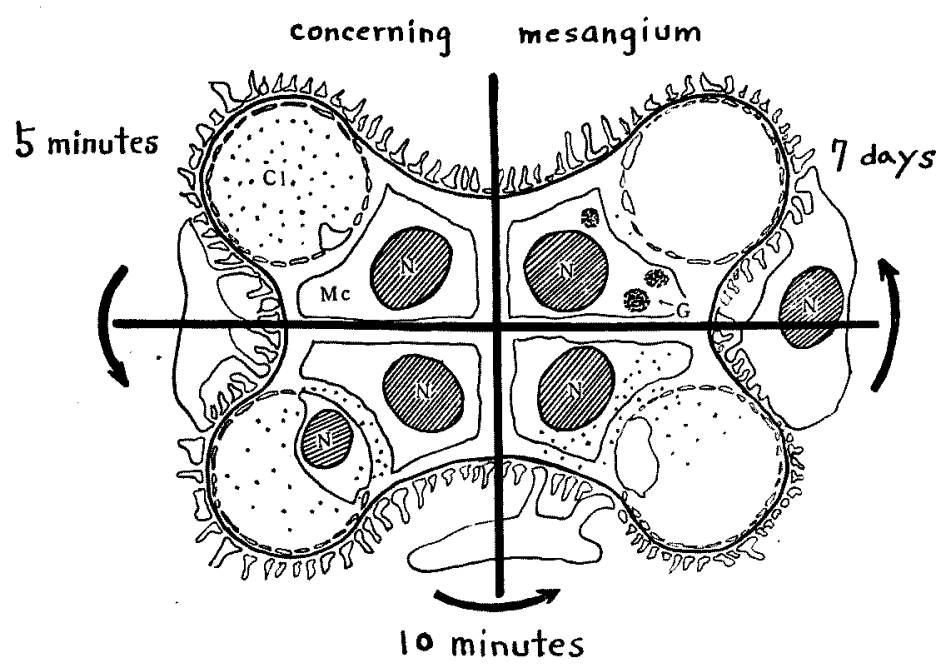

Fig. 3

be observed that once disheveled thin endothelial layer lost its peculiar small openings becoming tortile in shape and the foot processes of the epithelial cells also lost their characteristic features becoming much denser than normal and as flat as the above-mentioned endothelial layer.

These findings lead us to conclusion that, concerning the pathways of substances especially of the iron particles in penetrating the glomerular capillary wall, most possible one is from the small openings of the endothelial layer

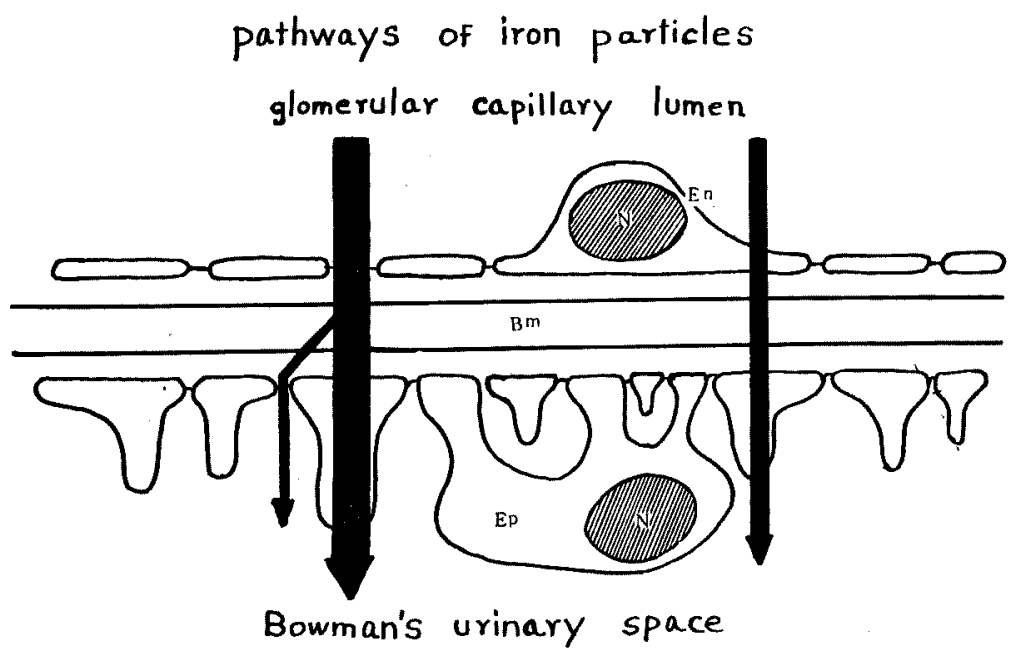

Fig. 4 
through the basement membrane to the foot processes. The second is either from the small openings to the urinary spaces between the foot processes, or from the endothelial cells, after penetrating them, into the foot processes. These possibilities are shown in the schema of Fig. 4: the bigger arrow, the greater possibility in glomerular permeability.

\section{DISCUSSION}

Iron dextran complex "Imferon" is a stable solution of ferric hydroxide colloid by low molecular dextran and said to be readily separated each other in the circulating blood, while in other opinion ferric hydroxide is rapidly liberated from the dextran in the reticuloendothelial system.(17-20) Therefore the permeability of Imferon is thought to be equal to that of ferric hydroxide.

In the series of the study some questions naturally arise. Firstly, a condition that Imferon in such dose is in the circulating blood and a large amount of ferric hydroxide penetrate the glomerular capillary wall is not physiological but abnormal. The dosage applied in the study is more intense than in practical usage for iron deficiency anemia, approximately ten times as much as therapeutic dosage. Golberg, Smith and Martin have already reported the effect of intensive and prolonged administration of Imferon parentrally in animals: in rabbits, within a week or two of starting the intramuscular injections of Imferon, massive proteinuria developed and in the survivers the proteinuria rapidly diminished and by the ninth week only a trace of protein remained in the urine.(1i) However, the effect of a short time method attempted in this study has not been reported yet. In the methods (3) and (4) no findings by light and electron microscopy were observed in the urine or no pathological observations in glomeruli such as plasma-like content in the urinary space, for instance. Therefore the author believes that the glomeruli showed nearly physiological functions of permeability for ferric hydroxide.

In the second place, as a matter of course, Imferon alone can not explain the permeability of whole substances which leak out of the glomerular capillary wall and this problem has not been completely understood. However, since water, for example, has substantially strong polarity, there is to some extent a possibility that iron particles are accompanied with water at the time of penetration through the glomerular capillary wall and the same consideration between water and other electrolytes would be allowed.

Identification of iron particles in the tissue under an electron microscope is also important. Small round particles with high density and distinct borders which exist in the glomerular capillary lumen, internal and external lucid layers, 
basement membrane and the Bowman's urinary space may be identified as the iorn particles from a standpoint of their size and locality, while it becomes a little difficult to differ them from RNA granules when they are individually scattered in the cytoplasm. Nevertheless, they are still denser and smaller.

Concerning the pathway of iron particles and their behavior in the glomerulus, Farquhar has already made great studies with the aid of ferritin as a tracer in rats in 1960 and 1961, $(15,16)$ According to her study, ferritin molecules introduced in the general circulation penetrated the endothelial openings and were seen at various levels in the basement membrane. In normal rats, when incorporated in the epithelium, a few ferritin molecules were seen in small invaginations of the cell membrane limiting the foot processes, within minute vesicles in the epithelium or within occasional large vacuoles and dense bodies. Thus ferritin molecules which penetrate the basement membrane are picked up the epithelium in pinocytotic vesicles and transported via the small vesicles to large vacuoles which are subsequently transformed into dense bodies by progressive condensation. The content of the dense bodies may then undergo partial digestion and be extruded into the urinary spaces where it disperses.

The author made nearly similar observations regarding the pathway of iron particles from the glomerular capillary lumen into the urinary space with exception of several different points. The majority of iron particles penetrate the endothelial openings, while a few or occasionally a considerable number enter into the endothelial cells as if the cell membrane had large holes and scattered throughout the cytoplasm without pinocytotic invagination or intracellular vesiculation. Then they are transported to the other side facing the basement membrane, penetrating again the cell membrane in like manner. Iron particles behave nearly in the same way as in the endothelium when incorporated by the epithelium, though rarely seen in some invaginations.

This manner of penetration of particles has been already reported by Wissig in 1958,(12) observing at the luminal surface of the endothelial cells in muscle of a rat, ferritin particles were either affixed to or imbedded within the plasma membrane, or were enclosed wthin vesicles. Beneath the plasma membrane some particles were within vesicles, but the great majority were free in the ground substance. In the pericapillary spaces, most particles were free, but a number were imbedded in the capillary basement membrane. It appears that relatively large molecules of select composition can penetrate the endothelium and basement membrane of capillaries in muscle. They enter endothelial cells by directly penetrating their plasma membrane or by being initially incorporated into vesicles. 
The author scarcely found invaginations or vesicles in the epithelial cells, while there were many in Farquhar's study. There are speculations for this in which ferritin molecules are composed of iron and protein, while Imferon is a solution of ferric hydroxide colloid by low molecular dextran which is easily separated from the dextran in the circulating blood.

When the animals were subjected by prolonged and repeated intramuscular injections, there were increased vesicular structures in the epithelial cells, in which iron particles were sometimes encountered. However a great majority of iron particles were free in the ground substance. They later formed groups in a week or so, becoming positive for iron staining just like hemosiderin granules in tissue. Dense bodies and their segregation mentioned by Farquhar were not found in this study but a few findings of extruding small vesicles containing serous fluid could be sometimes encountered (Fig. 20).

In regard to the mesangial cells, Latta in 1960 has reported permeability of centrolobular region (mesangium) with the aid of thorotrast. (22) The rapid and extensive penetration of thorotrast particles into the centrolobular region in high concentrations indicates that the passage having these particles constitute channels with intimate access to blood plasma and this special system of extravascular channels suggests that the centrolobular region has distinct functions. The author also observed the penetration of iron particles into the subendothelial spaces and considerable ability of mesangial cells in incorporating small particles and accumulating them in the same manner as in the epithelial cells, making them positive for iron staining. No channels, however, were found in the centrolobular region by means of methacrylate embedding.

\section{CONCLUSION}

Urographin, Fatgen and Imferon were used as tracers for the study of glomerular permeability. Imferon alone is large enough to be found under an electron microscope, penetrating the glomerular capillary wall, while the former two were unsuitable for the purpose.

In the method with Imferon, a great majority of iron particles penetrated the endothelial openings and basement membrane and were incorporated by the epithelial cells with or without invaginations of the cell membrane, transported freely in the ground substance, sometimes in vesicles or vacuoles, then penetrating again out of the epithelium and dispersed into the Bowman's urinary spaces. However some particles entered into the endothelial cells by directly penetrating their cell membrane and rarely existed between the foot processes. Prolonged and repeated intramuscular injections of Imferon revealed grouped iron particles 
in the epithelial cells as well as in the mesangial cells which became positive for iron staining like hemosiderin.

Thus the existing cells inside and outside of the basement membrane of the glomerular capillary wall appeared to play an important role in glomerular permeability, differently from the conventional views which presupposed holes in the every layer of the glomerular capillary walls.

This study was presented to the Japanese Society of Nephrology in October, 1960.

The author gratefully expresses thanks to Prof. Dr. T. Kobayashi, Assist. Prof. Dr. Y. Watanabe, Dr. H. Sakaguchi, Dr. Y. Suzuki and Dr. K. Arakawa for their cordial instructions and advices.

\section{REFERENCES}

1. Lölein, M.: Dtsch. Med. Wsch., 44: 1187, 1918.

2. Moench, A., et al.: Z. Exp. Med., 126: 471, 1955.

3. Farquhar, M. G., Vernier, R. L. and Good, R. A.: J. Exp. Med., 106: 649, 1957.

4. Vernier, R. L., et al.: Am. J. Dis. Child, 94: 514, 1957.

5. Heymann, W.: Klin. Wsch., 39: 293, 1958.

6. Oshima, K., et al.: Saishin Igaku (in Japanese), 14: 193, 1959.

7. Oshima, K. and Hatano, M.: Jap. J. Nephr. (in Japanese), 2: 295, 1960.

8. Brewer, D. B.: J. Micr. Sc., 95: 23, 1954.

9. Wallenius: Acta Soc. Med. Upsaleucis, 59, suppl., 4: 1, 1954.

10. Pappenheimer, J. R., Renkin, E. M. and Borrero, L.: Am. J. Physiol., 167: 13, 1951.

11. Pappenheimer, J. R.: Physiological Rev., 33: 387, 1953.

12. Pappenheimer, J. R.: Gättingen Nierensymposium, 1954: Klin. Wochschrift, 33: 362, 1955.

13. Hall, B. V.: Proc. 6th Ann. Conf. on the nephrotic syndrome, 1955.

14. Muller, C. B., et al.: Am. J. Med., 18: 267, 1955.

15. Farquhar, M. G. and Palade, G. E.: J. Biophysic. Biochem. Cytol. 7: 296, 1960.

16. Farquhar, M. G., Wissig, S. L. and Palade G,E, J. Exp. Med., 113: 47, 1961.

17. Golberg, L., Smith, J. P. and Martin, L. E. Yy. Exp. Path., 38: 297, 1957.

18. Nakano, Y., et al.: Nihon Rinsho, 17: 1863, 1959. (in Japanese)

19. Grimes, A. J. and Hutt, M. S. R.: Brit. Med. J., 2: 1074, 1957.

20. Fletscher, F. and London, E.: Brit. Med. J., 1: 984, 1954.

21. Wissig, S. L.: Anat. Rec., 130: 467, 1958.

22. Latta, H., Maunsbach, A. B. and Madden, S. C.: J. Ultrastructure Research, 4: $455,1960$. 


\section{EXPLANATION OF PLATES}

Fig. 5. In 5 minutes following intravenous injection of Imferon iron particles (Ip) are seen in the glomerular capillary lumen $(\mathrm{Cl})$, showing high density with round and distinct borders.

Fig. 6. In 10 minutes iron particles (Ip) penetrate the endothelial openings into the lamina lucida interna and basement membrane.

Fig. 7. Some particles are in a small invagination of the foot process in 10 minutes.

Fig. 8. Iron particles are seen on the surface of the endothelial cells (En) and scattered throughout the cytoplasm without invagination of the cell membrane or intracellular vesiculation.

Fig. 9. The thin endothelial layer is irregular (Ie) and the internal lucid layer is enlarged where iron particles are seen.

Fig. 10. Iron particles are seen in the Bowman's urinary space (Us) within 10 minutes.

Fig. 11. An iron particle (arrow) is seen between the foot processes of the epithelial cell $(\mathrm{Ep})$.

Fig. 12. This photograph shows findings in six to twelve hours which reveal the same results as in 10 minutes.

Fig. 13. In twelve hours following intramuscular injection, vesicular structures in the epithelial cell $(E p)$ such as rough-surfaced endoplasmic reticulum, vesicles (Vs) and vacuoles.

Fig. 14. This photograph shows one of the increased vesicular structures in the epithelial cell, a vacuole (Vo) in which some iron particles are seen.

Fig. 15. In twenty-four hours iron particles are scattered throughout the epithelial cell (Ep) which subsequently appears dark.

Fig. 16. Iron particles form themselves groups (G) in the epithelial cell within a week, which are positive for iron staining.

Fig. 17. In 10 minutes iron particles also penetrate into the subendothelial space (mesangial matrix).

Fig. 18. And they are seen in the mesangial cell (Mc) in the same period.

Fig. 19. In a week iron particles group together in the mesangial cell becoming positive for iron staining in the same manner as in the epithelial cell.

Fig. 20. Small vesicles (Vs) are being extruded from the epithelial cell in twelve hours.

\section{NOMENCLATURE}

$\mathrm{Bm}$ basement membrane

Cl glomerular capillary lumen

En endothelium

Ep epithelium

$\mathrm{G}$ group of iron particles

Ip iron particle

Iv invagination of the cell membrane
Ie irregularity of endothelial layer

Mc mesangial cell

MN nucleus of mesangial cell

$\mathrm{N}$ nucleus

Us urinary space

Vs vesicle

Vo vacuole 


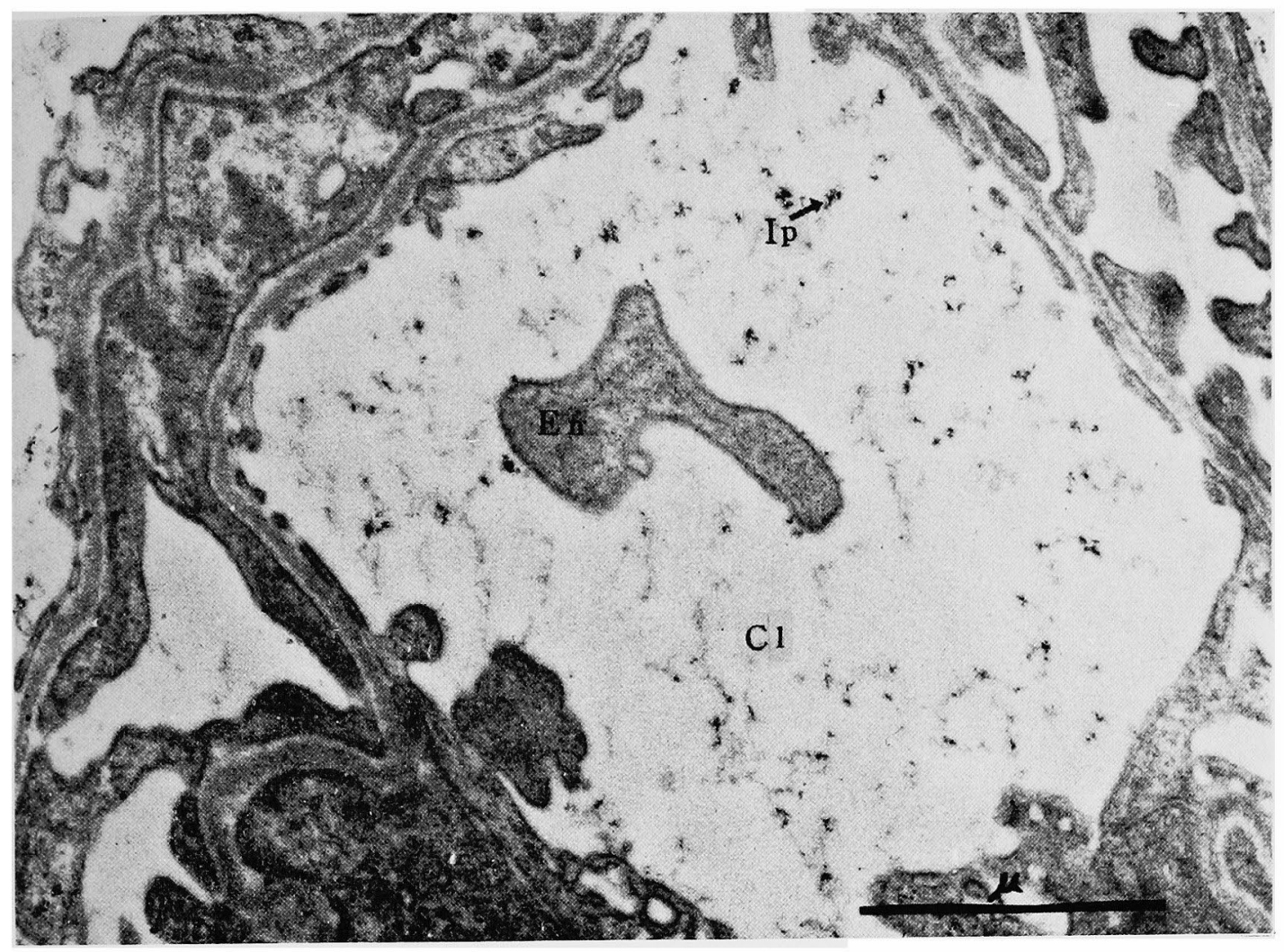

Fig. 5

$\times 35,000$

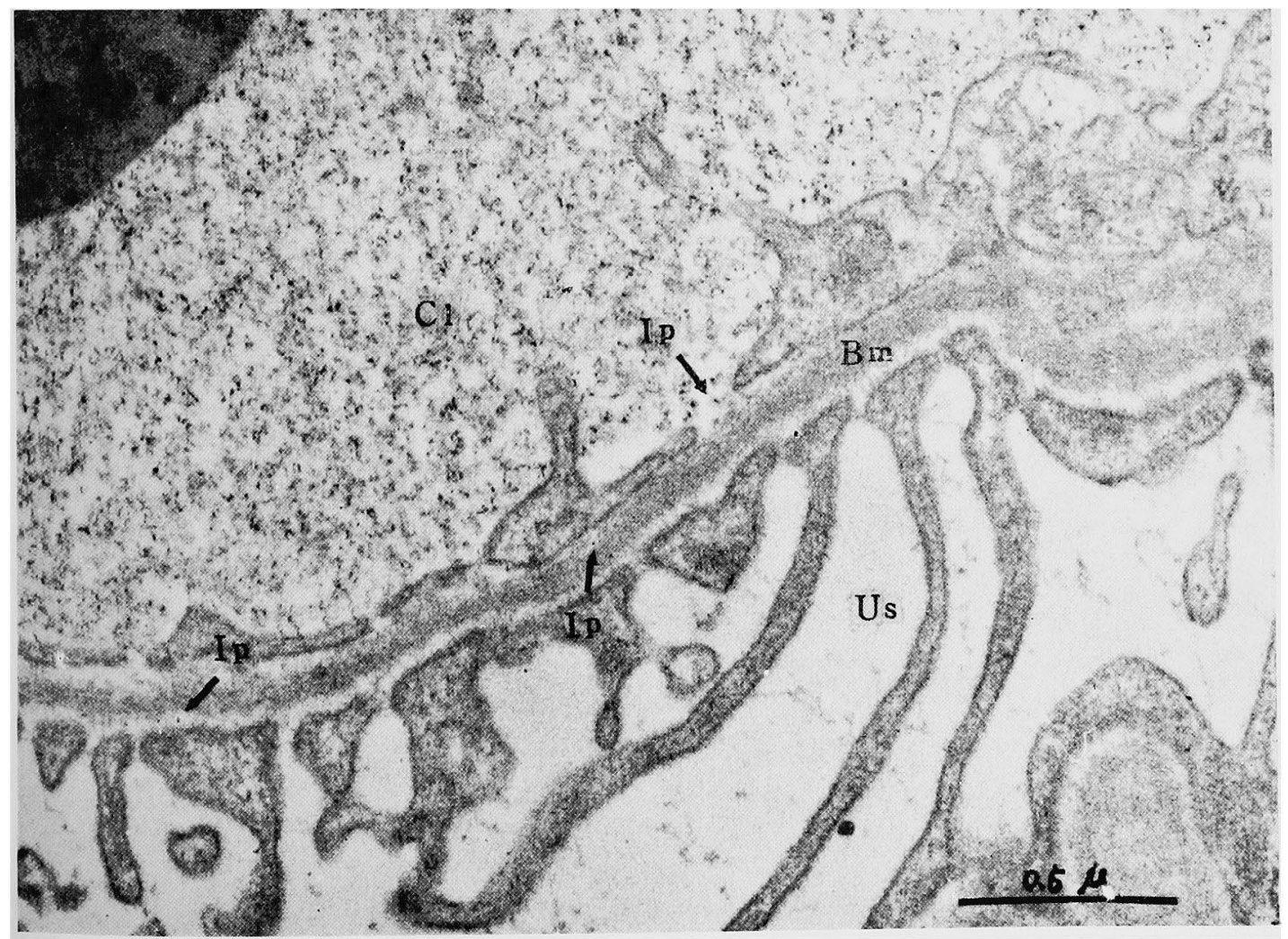

Fig. 6

$\times 50,000$ 


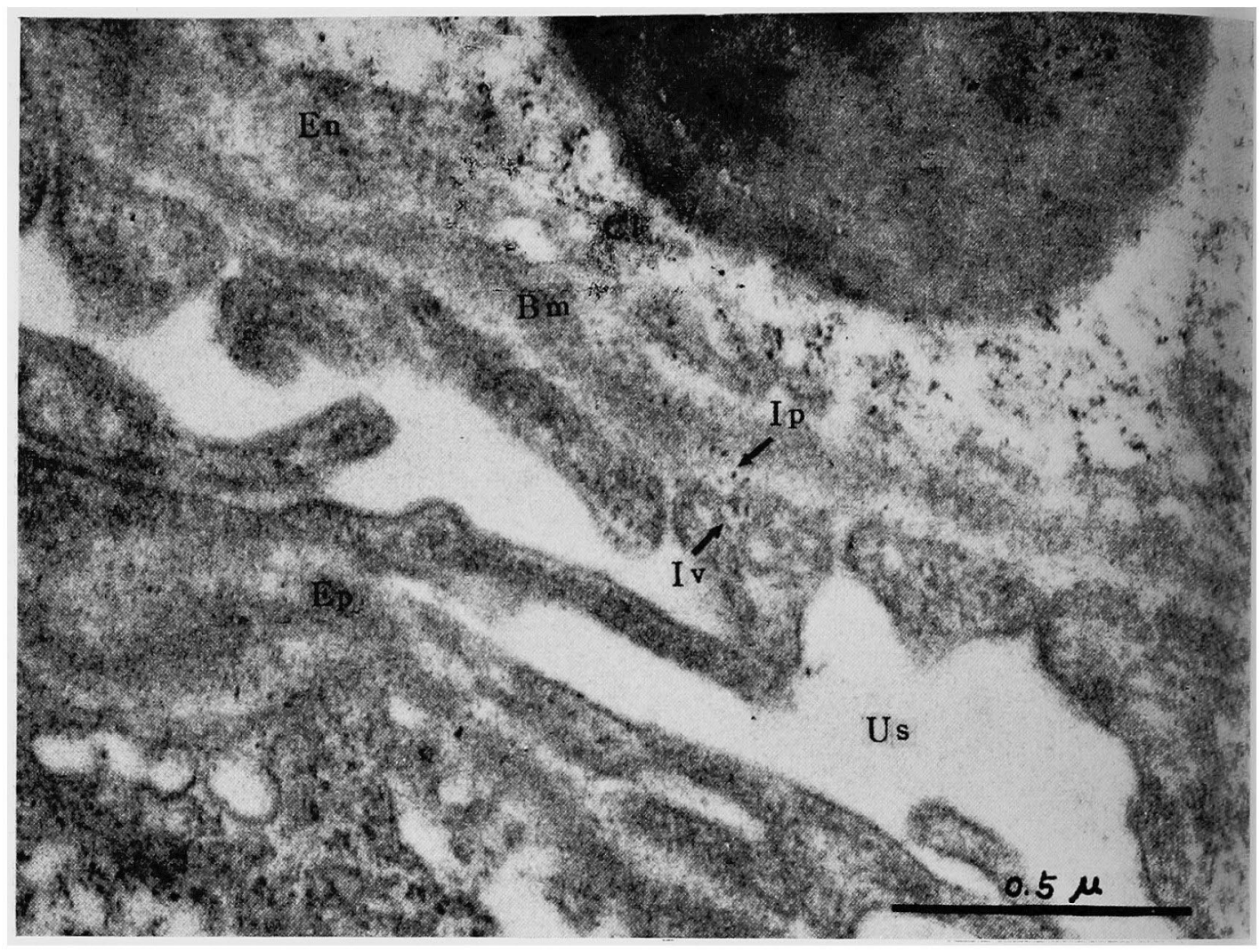

Fig. 7

$\times 70,000$

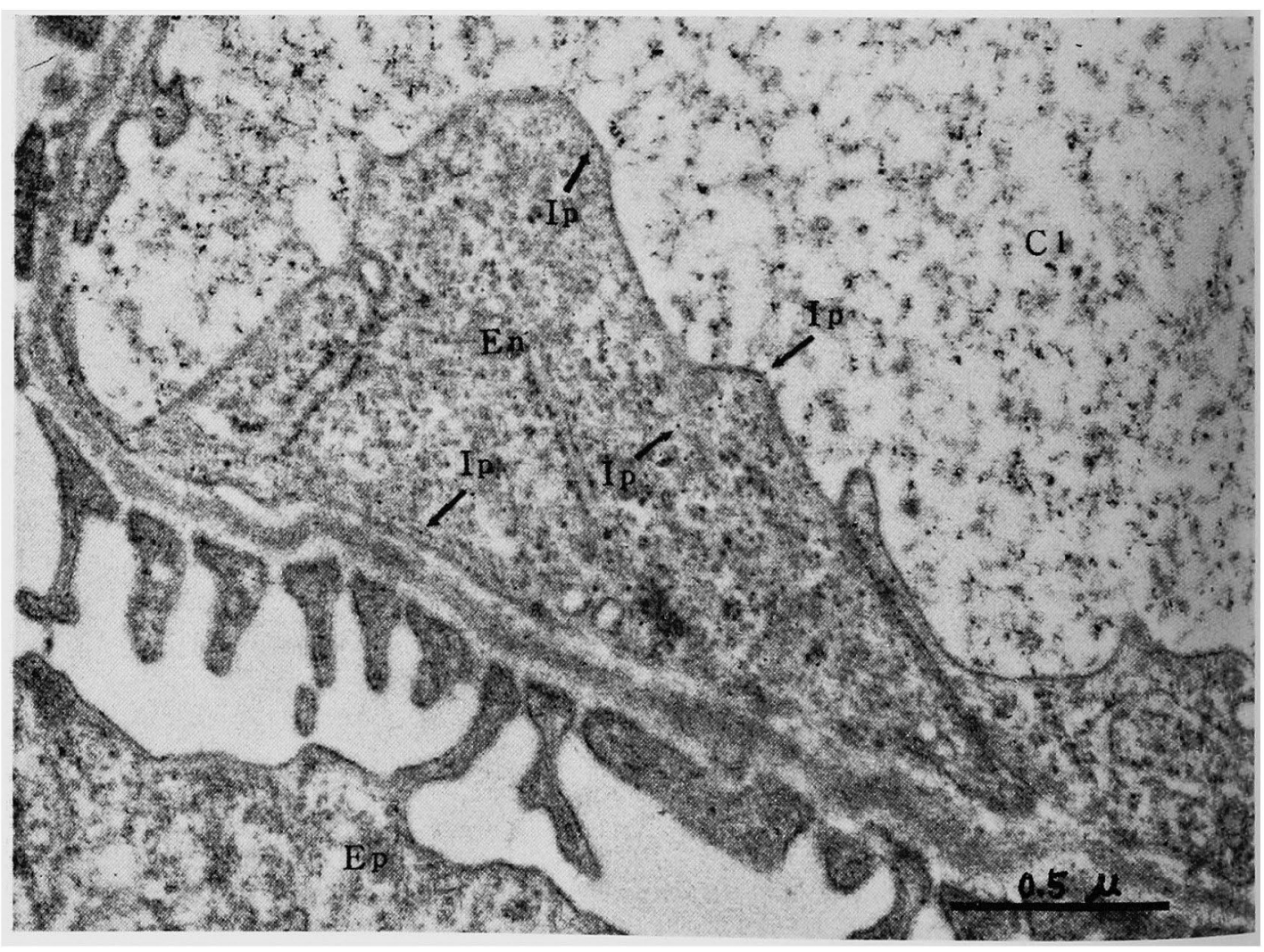

Fig. 8 


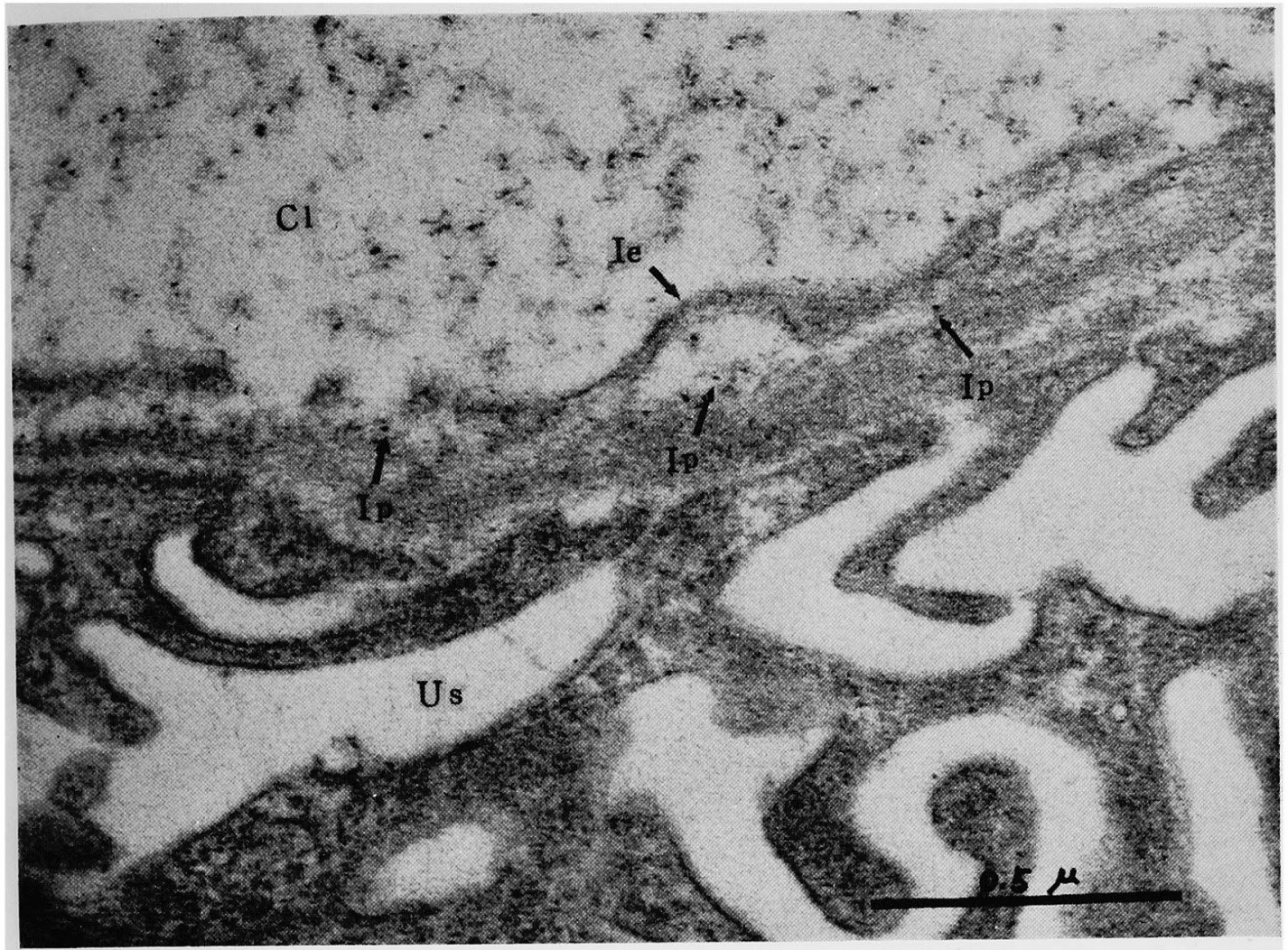

Fig. 9

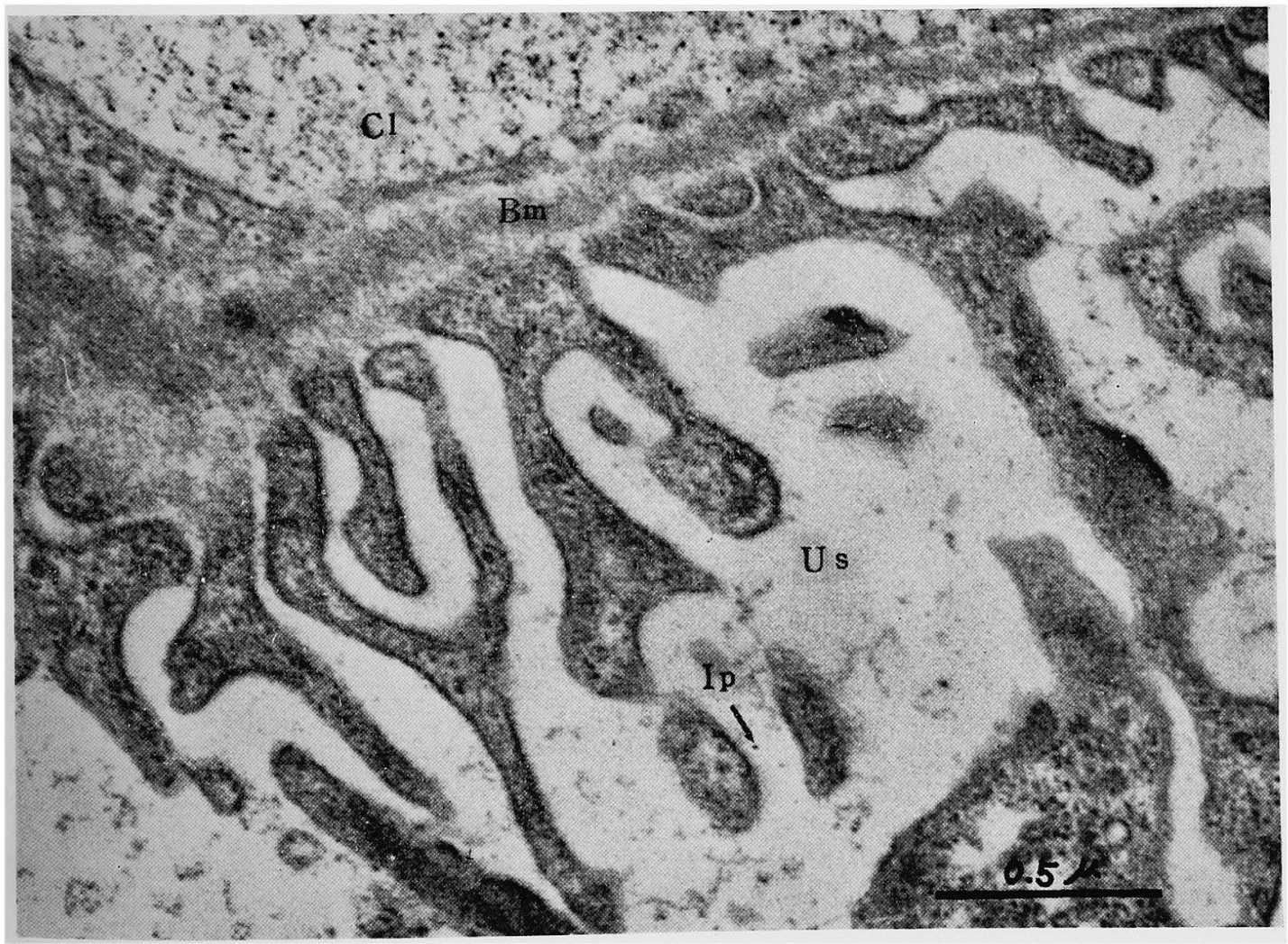




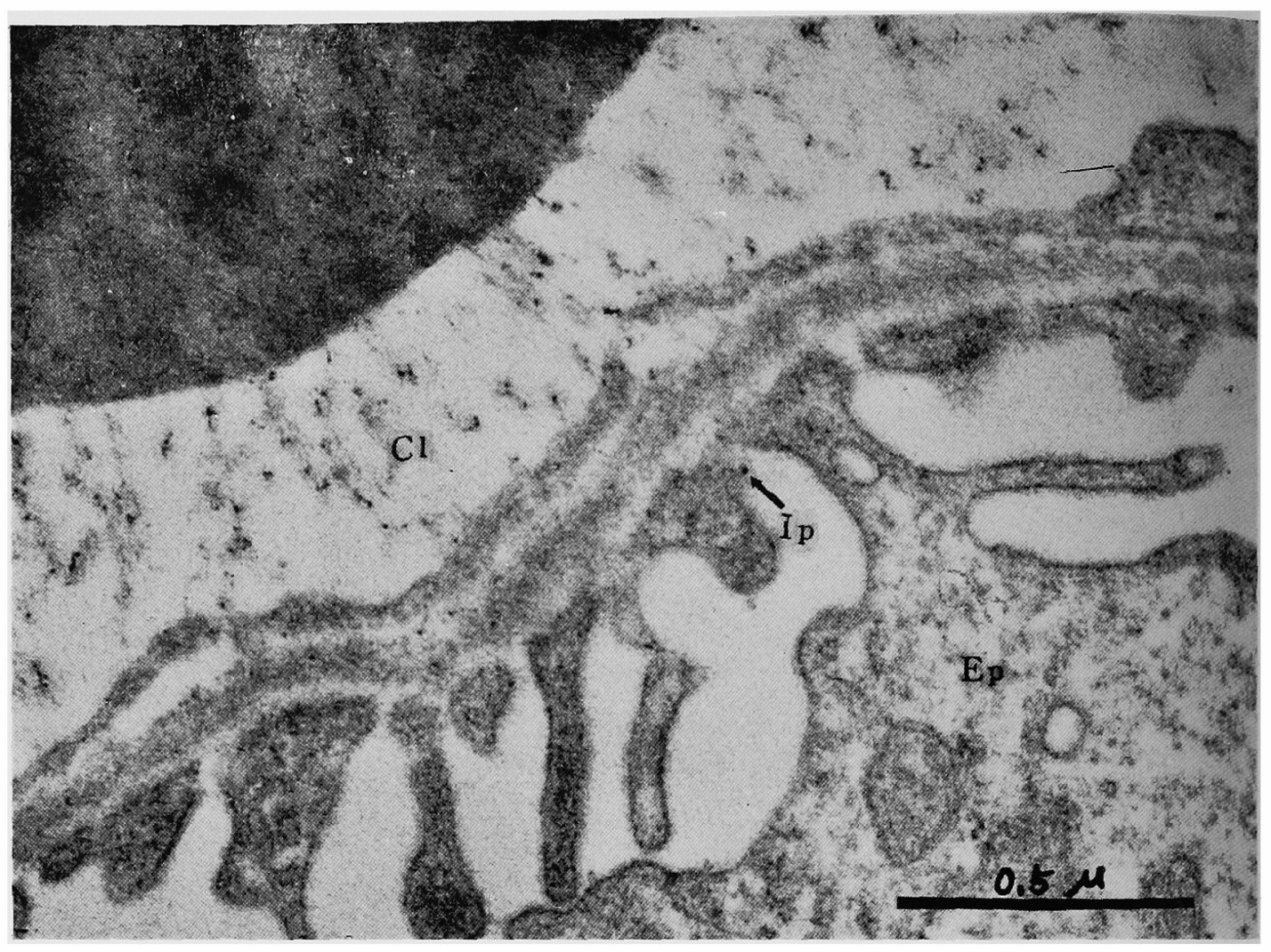

Fig. 11

$\times 70,000$

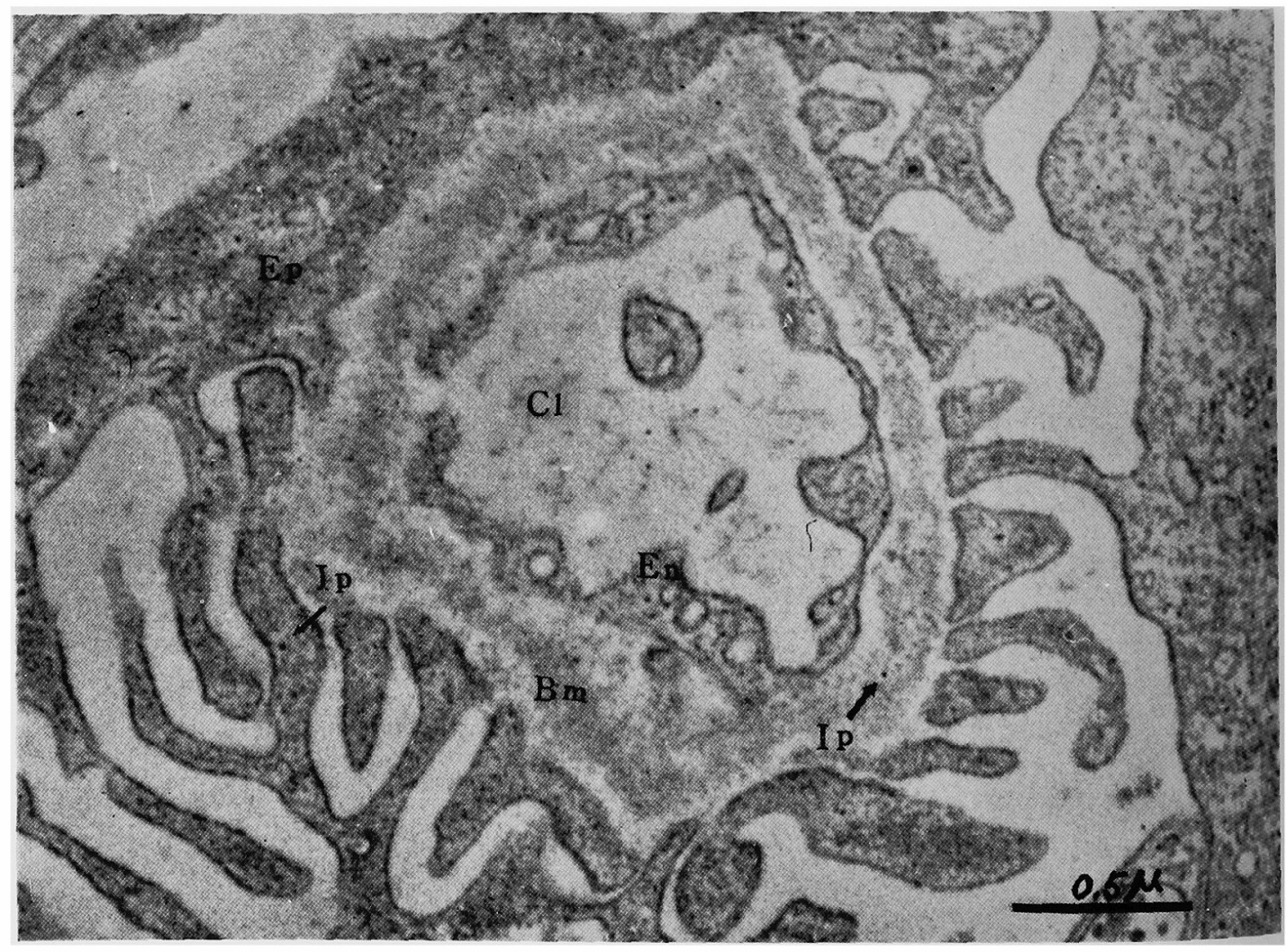

Fig. 12

$\times 40,000$ 


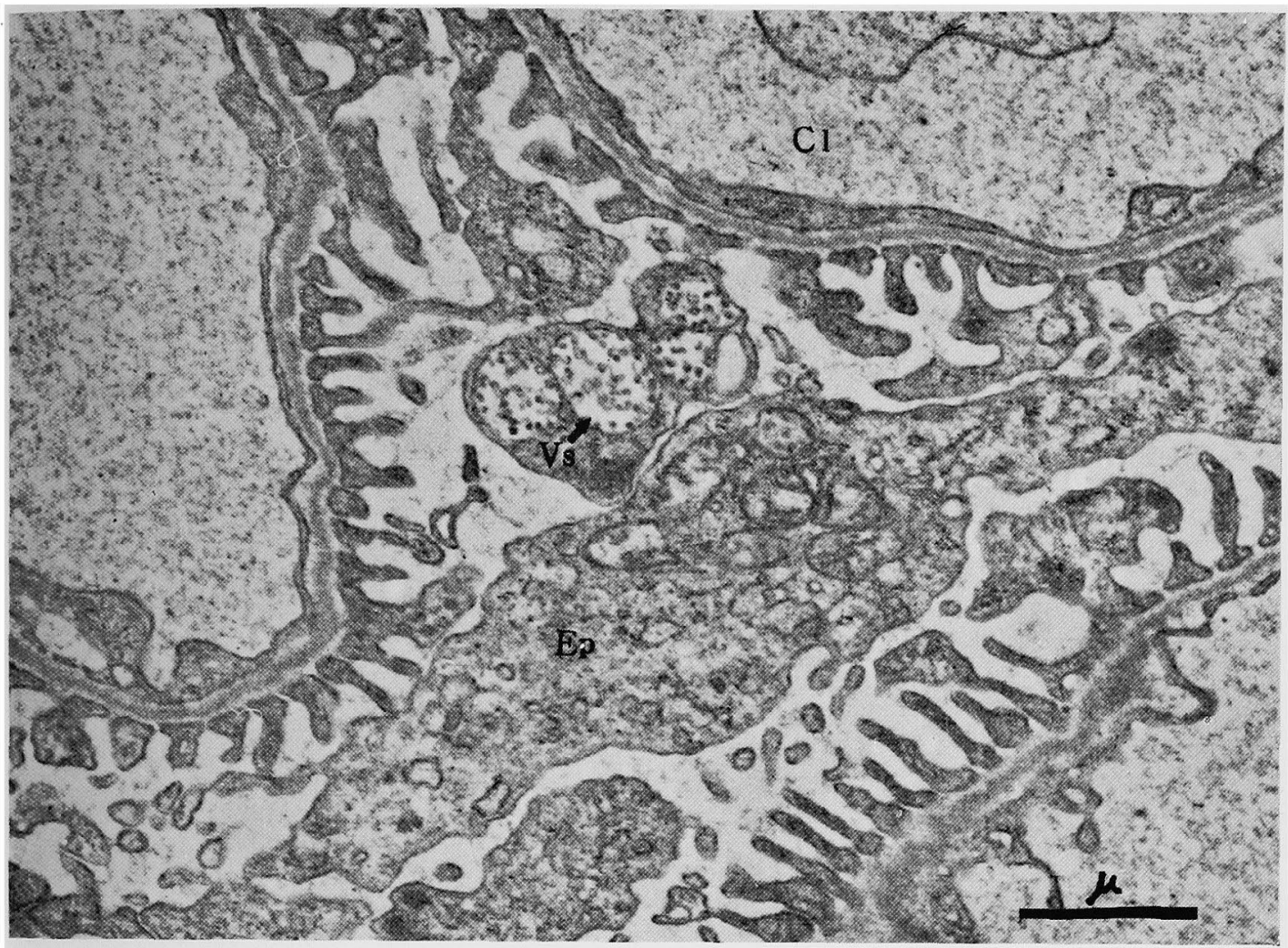

Fig. 13

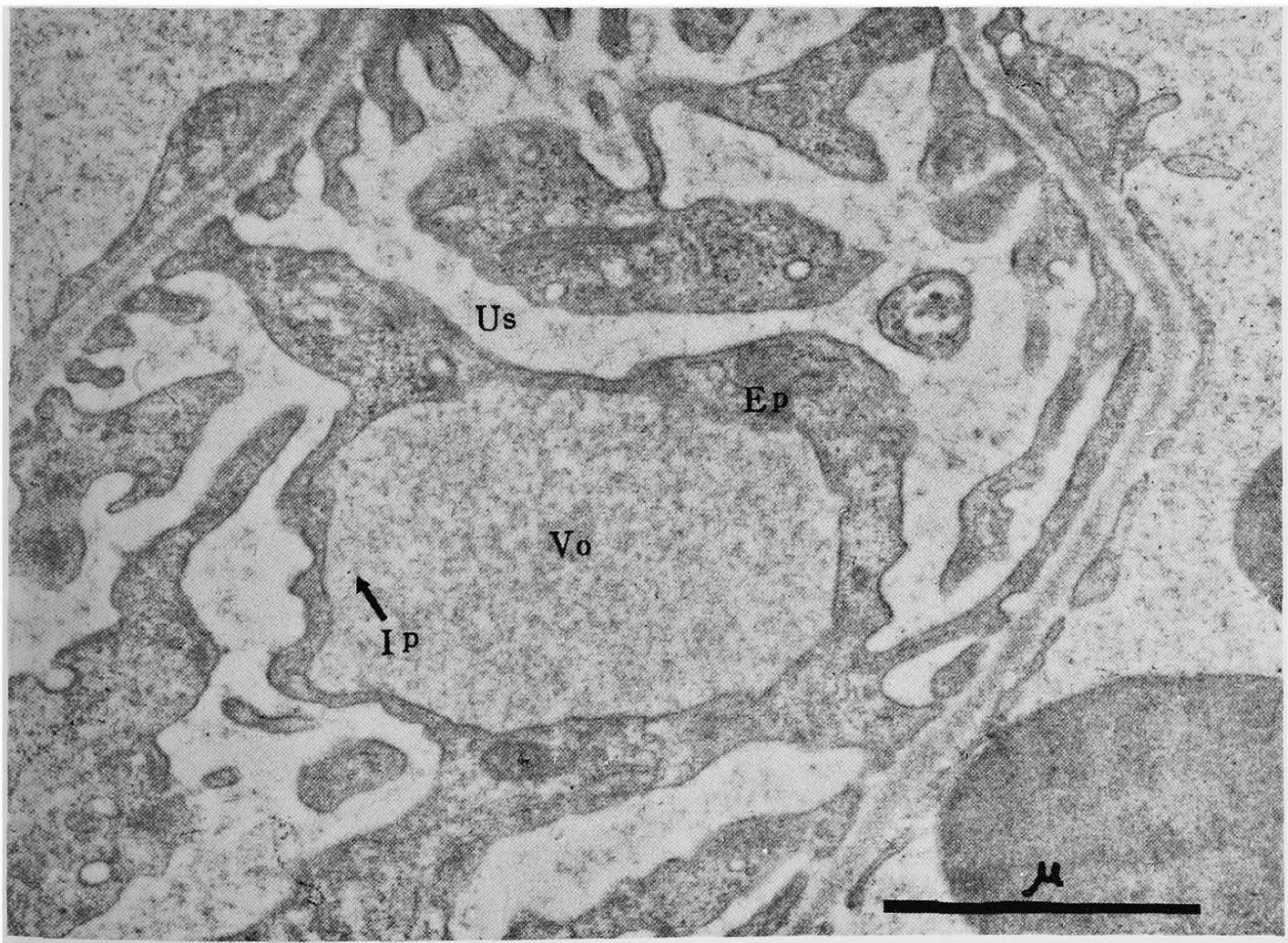

Fig. 14

$\times 35,000$ 


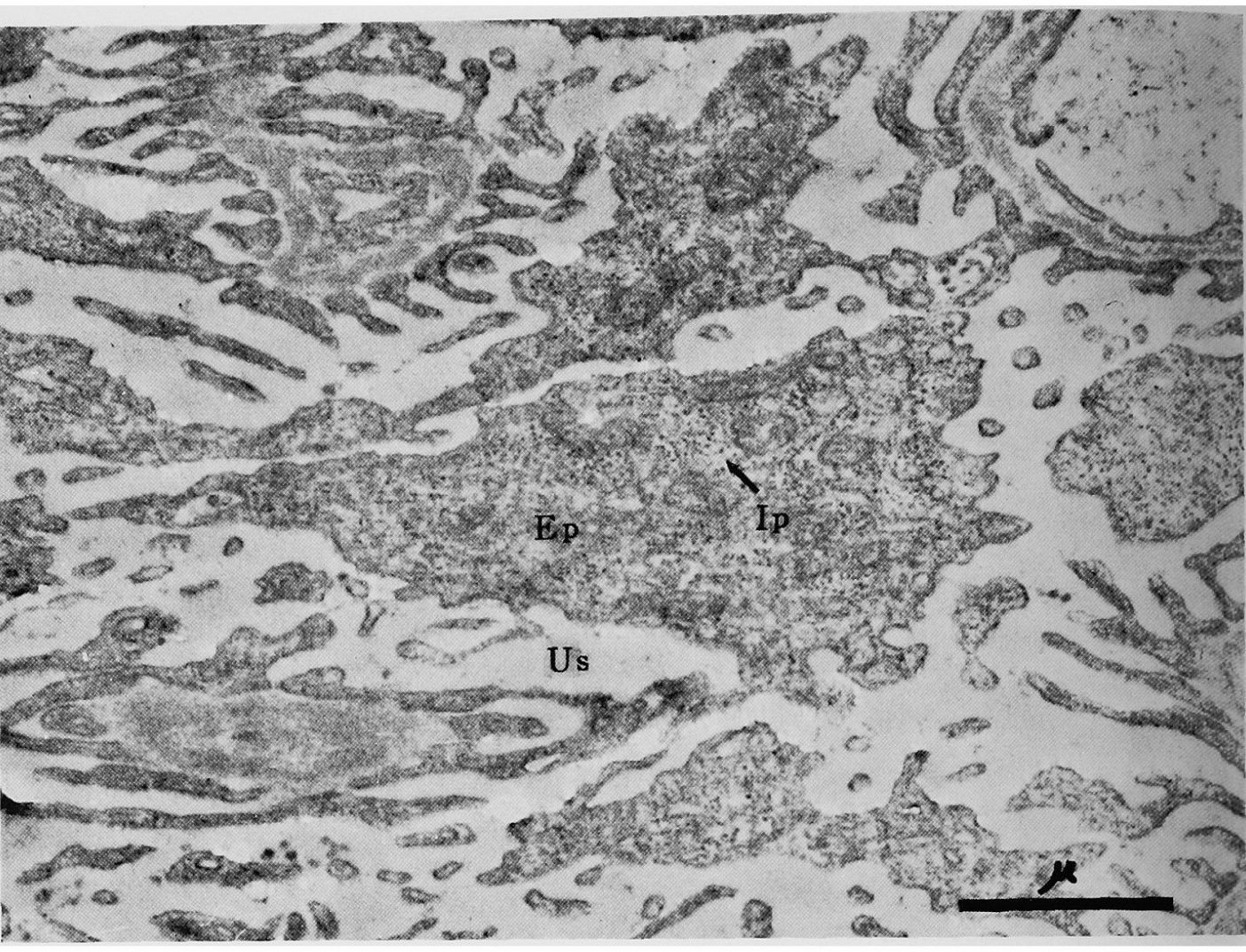

Fig. 15

$\times 25,000$

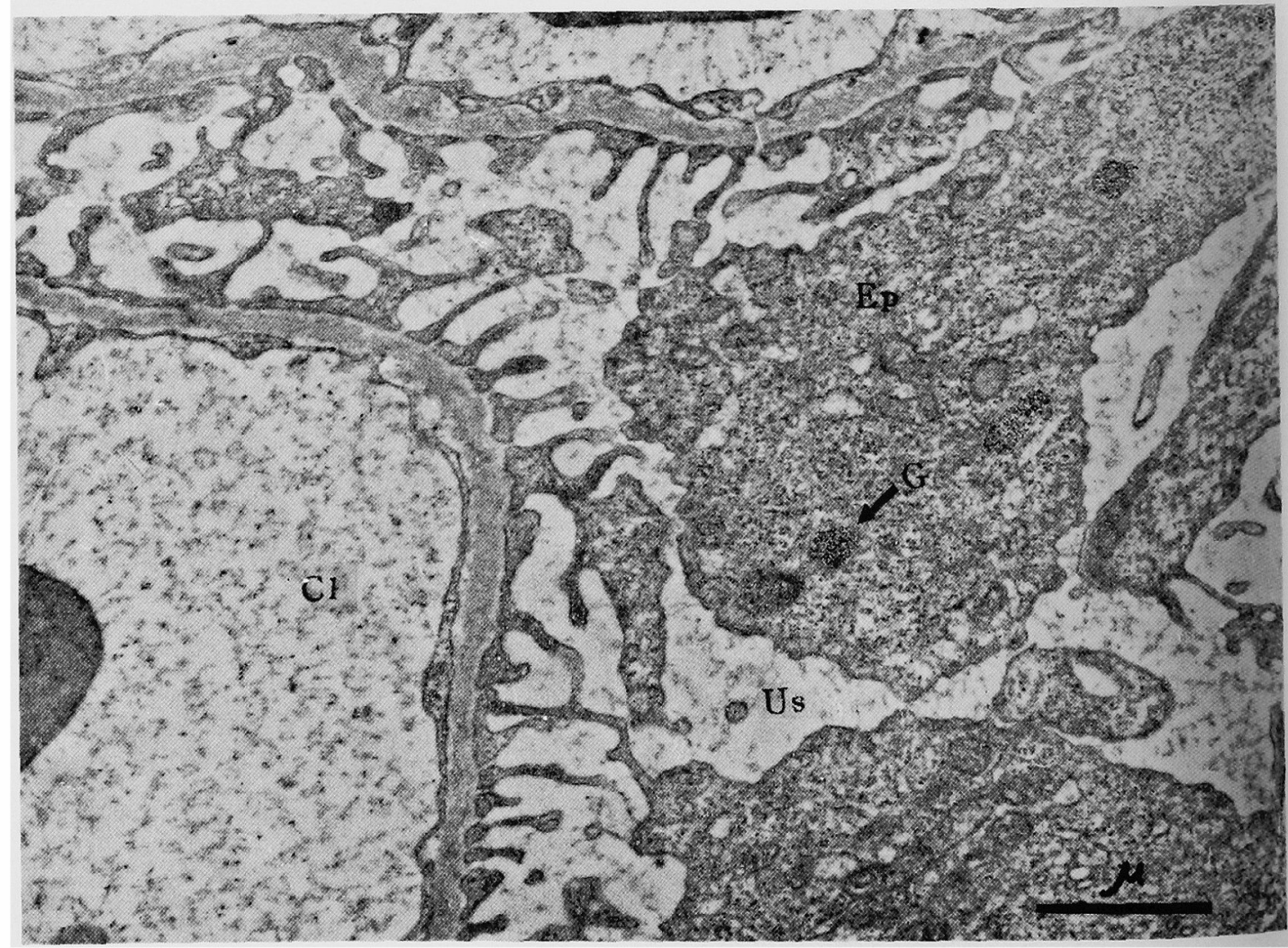

Fig. 16 

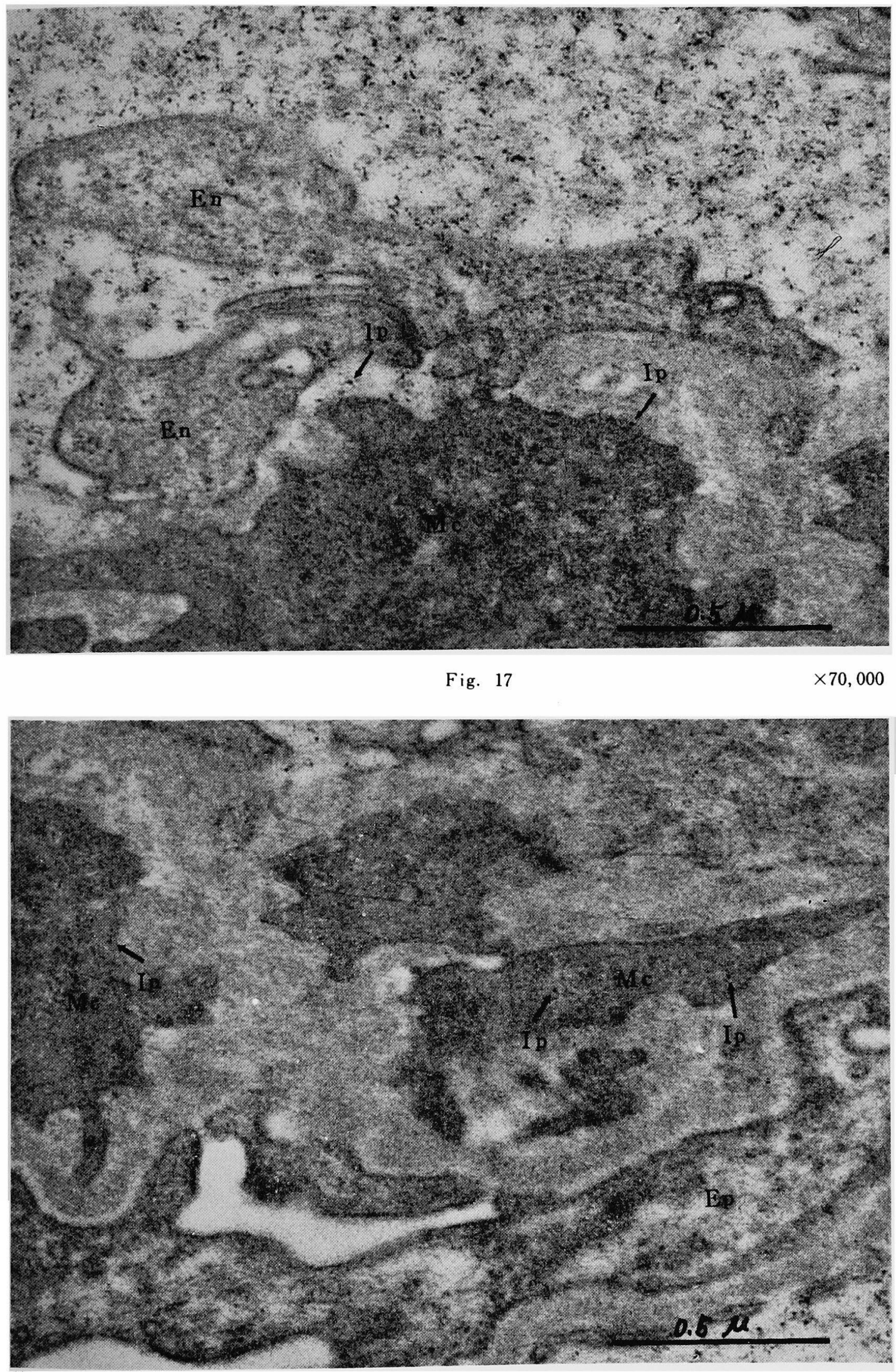


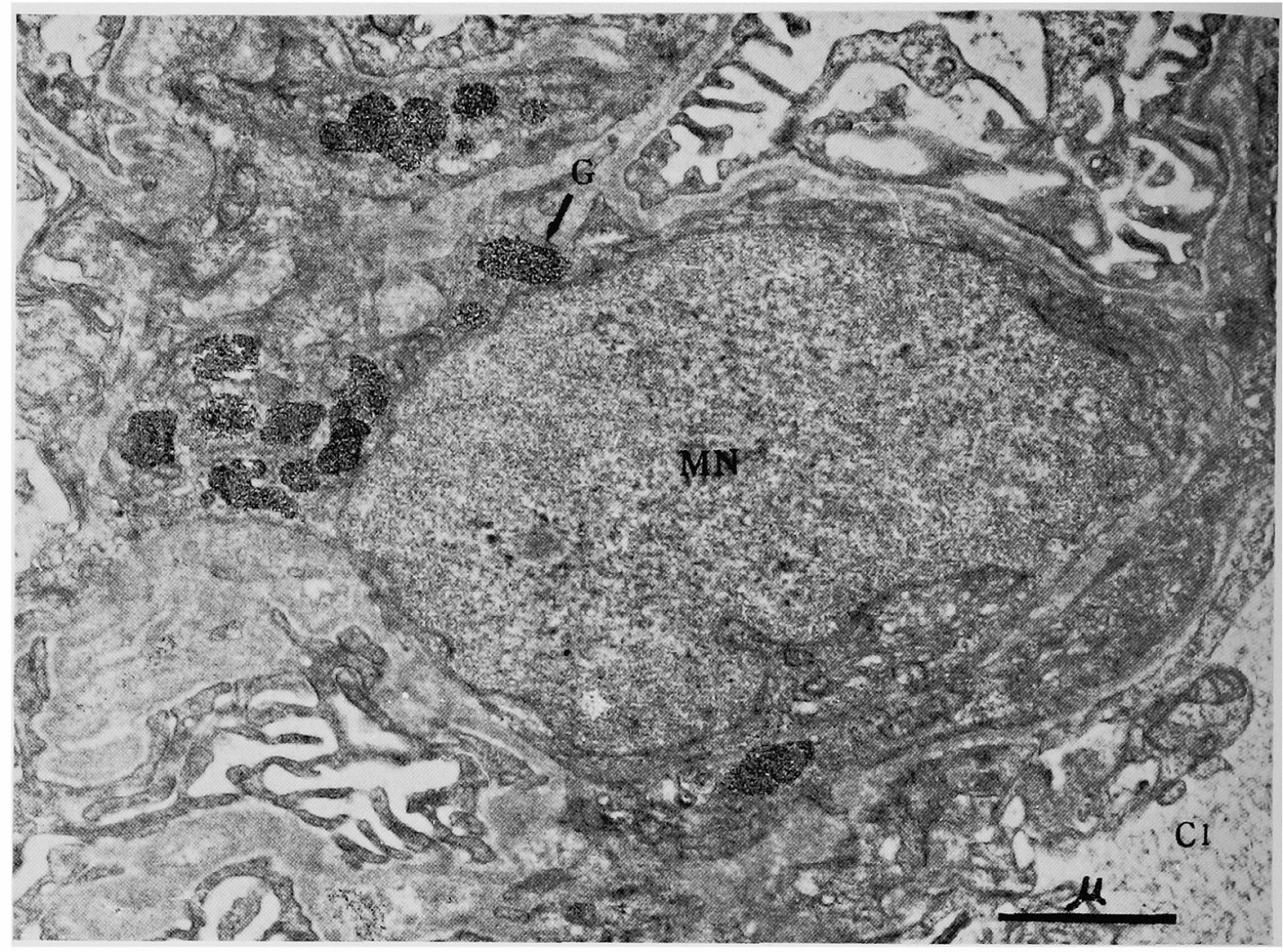

Fig. 19

$\times 20,000$

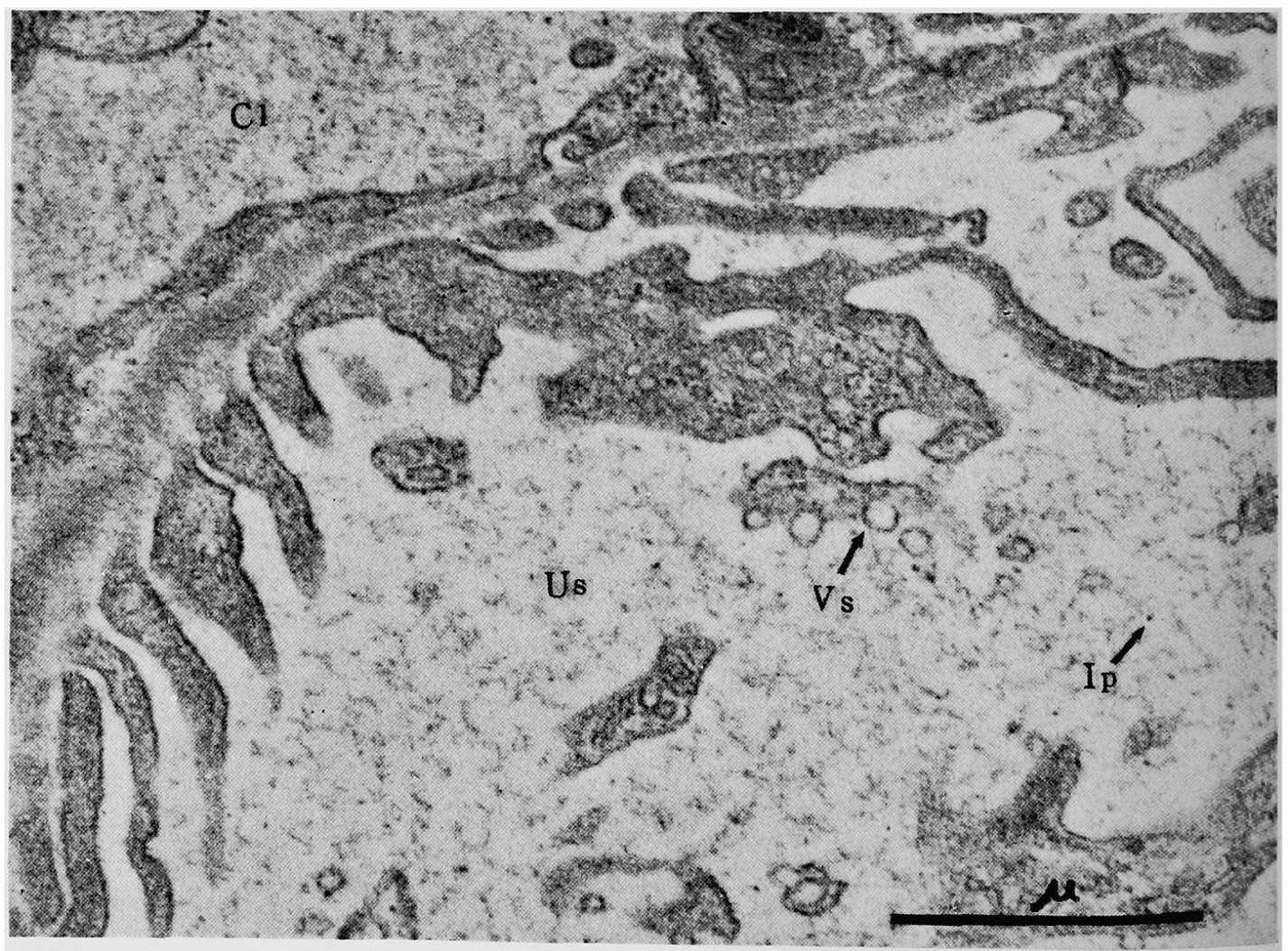

Fig 20. 